moisture than that corresponding to the saturation vapour pressure of water, several jute bundles were soaked in distilled water for $15 \mathrm{~min}$., squeezed and allowed to dry in a slow current of air at about 60 per cent relative humidity. At different intervals of time the bundles were taken one after another and put into stoppered bottles to allow the interior and the surface moisture to reach equilibrium. After one hour (which is not, however, sufficient for equilibrium), each bundle was tested for friction. Immedi-

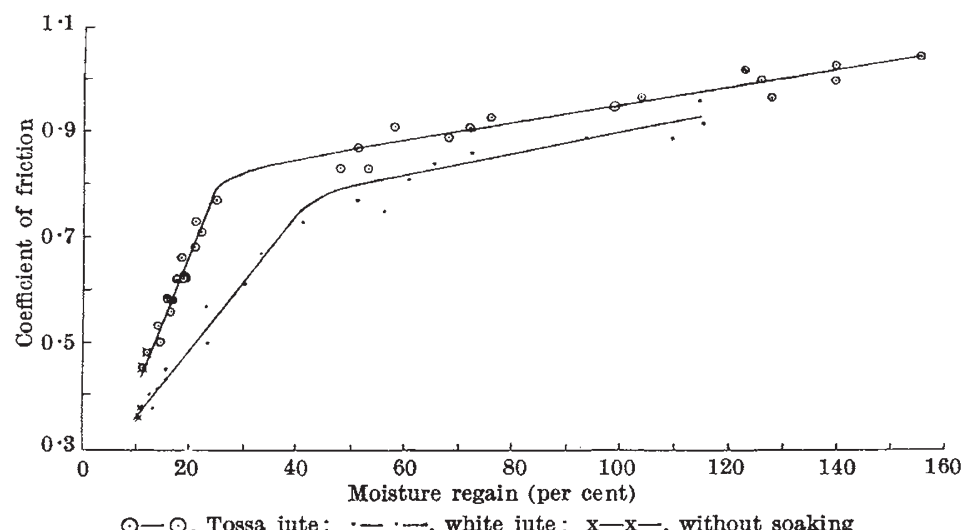

\section{A New Cholinesterase in Swine Serum}

THERE are at present two groups of enzymes in mammals which hydrolyse acetylcholine: the first hydrolyses acetylcholine and acetyl- $\beta$-methylcholine and is found primarily in nervous tissue and red blood cells ; the second group hydrolyses acetylcholine and benzoylcholine and is found in the serum and tissues of some animal species. Characteristic of this last group is the enzyme in human serum. In addition, there is one other related enzyme or group of enzymes which hydrolyses benzoylcholine but not acetylcholine. This was first noted and labelled benzoylcholinesterase by Sawyer ${ }^{1}$, and was reported by us as occurring in rabbit serum ${ }^{2}$.

We are now reporting a new enzyme which hydrolyses acetylcholine, but neither benzoylcholine nor acetyl- $\beta$ methylcholine to any significant degree. This enzyme was observed in swine serum, and was found to yield 160 to 260 microlitres carbon dioxide per c.c. in eight pigs studied. The methods of determination are identical with those described by us in a recent paper ${ }^{2}$.

Pontocaine inhibition has been used in the classi. fication of these enzymes. Swine serum cholinesterase activity is inhibited completely by $10^{-4} M$ pontocaine, and in this respect is similar to the cholinesterase of human serum. However, the human serum enzyme hydrolyses acetylcholine and benzoylcholine in a constant ratio, and since the swine serum does not hydrolyse benzoylcholine, it must be considered a separate enzyme.

\section{Milton Gjelmaug Levine* Anita A. Suran} cent. The readings for the individual bundles of two
varieties of jute have been plotted in the accompanying graph. The curves are for desorption.

The interesting features of the curves are that: (1) each of them shows two distinct linear regions at low and high regains, with a short curved region intervening, between 25 and 40 per cent regain in one case and 35 and 50 per cent in another, indicating a change of behaviour of the fibre surface as it passes from one region to the other; and (2) at lower regains, the friction is rather sensitive to moisture, though not equally for both the fibres, whereas above 50 per cent regain the effect is less pronounced, being practically the same for both.

A probable explanation seems to be that the water molecules adsorbed on the fibre surface (but not in the interior) form a bond between the pads, and as the number of such bonds increases, friction correspondingly increases; after a certain stage, when a multilayer film has been formed, the proportion of water molecules contributing to the surface bonding falls and the slope of the curve diminishes.

This may throw some light on the mechanism of moisture adsorption on the fibre surface at different moisture conditions. Further work on these lines is in progress.

\section{S. B. Bandyopadhyay}

Technological Research Laboratories,

Indian Central Jute Committee,

Calcutta, 33.

$$
\text { June } 5 \text {. }
$$

1 Pollitt, J. Text. Inst., 41, P1 (1950).

- Morrow, J. Text. Inst., 22, T425 (1931).

\section{Institute of Experimental Medicine, White Memorial Hospital, Los Angeles 33, California. June 6.}

* Present address: Kabat-Kaiser Institute, Vallejo, California. 1 Sawyer, C. H., Science, 101, 385 (1945).

2 Levine, M. G., Hoyt, R. E., and Suran, A. A., Proc. Soc, Exp. Biol. and Med., 73, 100 (1950).

\section{Alkaline Hydrolysis of Trichothecin}

THE preparation, and biological and preliminary chemical properties of trichothecin, an antifungal substance from Trichothecium roseum link, have been described $^{1}$. From the data then available it was erroneously concluded that the compound was a lactone with the probable molecular formula $\mathrm{C}_{15} \mathrm{H}_{20} \mathrm{O}_{4}$. Further work has shown that trichothecin is an ester, $\mathrm{C}_{19} \mathrm{H}_{24} \mathrm{O}_{5}$, the components of which are isocrotonic acid and a ketonic alcohol, trichothecolone.

The antifungal compound gave on analysis (Weiler and Strauss) $\mathrm{C}=68 \cdot 9,68 \cdot 5,68 \cdot 7,68 \cdot 8,68 \cdot 9 ; \mathrm{H}=$ $7 \cdot 2,7 \cdot 2,7 \cdot 3,7 \cdot 4,7 \cdot 5$ per cent; mol. wt. (Rast) $=$ $332,312,320 ; \mathrm{C}_{18} \mathrm{H}_{24} \mathrm{O}_{5}$ requires : $\mathrm{C}=68 \cdot 6 ; \mathrm{H}=$ $7 \cdot 3$ per cent; mol. wt. $=332$. Trichothecin $2: 4$ dinitrophenylhydrazone (m.p. $203^{\circ}$ ) gives $\mathrm{C}=58 \cdot 6$, $58.7 ; \mathrm{H}=5.2,5.2 ; \mathrm{N}=10.5,10.8$ per cent; $\mathrm{C}_{25} \mathrm{H}_{28} \mathrm{O}_{8} \mathrm{~N}_{4}$ requires : $\mathrm{C}=58 \cdot 6 ; \mathrm{H}=5.5 ; \mathrm{N}=$ 